\title{
A Disjunctive Marginal Edge of Evergreen Broad-Leaved Oak (Quercus gilva) in East Asia: The High Genetic Distinctiveness and Unusual Diversity of Jeju Island Populations and Insight into a Massive, Independent Postglacial Colonization
}

\author{
Eun-Kyeong Han ${ }^{1,+}\left(\mathbb{D}\right.$, Won-Bum Cho ${ }^{2,+} \oplus$, Jong-Soo Park ${ }^{3}$, In-Su Choi ${ }^{4}$, Myounghai Kwak ${ }^{5}$, \\ Bo-Yun Kim ${ }^{6}$ and Jung-Hyun Lee ${ }^{2, *}$ \\ 1 Department of Biological Sciences and Biotechnology, Chonnam National University, Gwangju 61186, Korea; \\ urinara-han@hanmail.net \\ 2 Department of Biology Education, Chonnam National University, Gwangju 61186, Korea; \\ rudis99@hanmail.net \\ 3 Department of Biological Sciences, Inha University, 100, Inha-ro, Michuhol-gu, Incheon 22212, Korea; \\ beeul25@gmail.com \\ 4 School of Life Sciences, Arizona State University, Tempe, AZ 85287, USA; 86ischoi@gmail.com \\ 5 Biological and Genetic Resources Utilization Division, National Institute of Biological Resources, \\ Incheon 22689, Korea; mhkwak1@korea.kr \\ 6 Plant Resources Division, National Institute of Biological Resources, Incheon 22689, Korea; \\ bykim416@korea.kr \\ * Correspondence: quercus@jnu.ac.kr \\ $\dagger$ These authors contributed equally to this work.
}

Received: 13 August 2020; Accepted: 22 September 2020; Published: 23 September 2020

\begin{abstract}
Jeju Island is located at a marginal edge of the distributional range of East Asian evergreen broad-leaved forests. The low genetic diversity of such edge populations is predicted to have resulted from genetic drift and reduced gene flow when compared to core populations. To test this hypothesis, we examined the levels of genetic diversity of marginal-edge populations of Quercus gilva, restricted to a few habitats on Jeju Island, and compared them with the southern Kyushu populations. We also evaluated their evolutionary potential and conservation value. The genetic diversity and structure were analyzed using 40 polymorphic microsatellite markers developed in this study. Ecological Niche Modeling (ENM) has been employed to develop our insights, which can be inferred from historical distribution changes. Contrary to our expectations, we detected a similar level of genetic diversity in the Jeju populations, comparable to that of the southern Kyushu populations, which have been regarded as long-term glacial refugia with a high genetic variability of East Asian evergreen trees. We found no signatures of recent bottlenecks in the Jeju populations. The results of STRUCTURE, neighbor-joining phylogeny, and Principal Coordinate Analysis (PCoA) with a significant barrier clearly demonstrated that the Jeju and Kyushu regions are genetically distinct. However, ENM showed that the probability value for the distribution of the trees on Jeju Island during the Last Glacial Maximum (LGM) converge was zero. In consideration of these results, we hypothesize that independent massive postglacial colonization from a separate large genetic source, other than Kyushu, could have led to the current genetic diversity of Jeju Island. Therefore, we suggest that the Jeju populations deserve to be separately managed and designated as a level of management unit (MU). These findings improve our understanding of the paleovegetation of East Asian evergreen forests, and the microevolution of oaks.
\end{abstract}

Keywords: marginal edge; Quercus gilva; genetic diversity; massive colonization; Jeju Island; conservation 


\section{Introduction}

It is well known that the population genetic structure in extant plants is affected by various factors, including the dispersal ability of pollinators, seed dispersal modes, reproductive systems, and historical migration patterns; the historical range change during Quaternary climatic oscillations is also considered a primary factor [1-3]. Although their relative importance may vary across time and space, the genetic features of populations in East Asian temperate regions likely reflect historical, rather than current, levels of gene flow [4-8]. East Asia has experienced complex and dynamic changes in land configurations during the Quaternary period, which led to a high richness and endemism of plant species in forests [9]. The range change of warm temperate evergreen forests was larger than that of temperate deciduous forests, especially in Korea and Japan.

Peripheral, especially marginal/edge, populations, might reflect genetic impoverishment as a result of genetic drift and reduced gene flow when compared to core populations [10-13]. Such genetic determinants have the potential to further expand species ranges through adaptation to the selection pressures of a marginal environment, assumed to furnish less fitness for their survival [14]. The populations have played decisive roles for species facing and responding to rapidly changing environmental conditions $[15,16]$. Many of these studies of local fitness have improved our knowledge of how a given species adapts to a changing environment $[17,18]$. Nonetheless, our understanding of the evolution of species in warm temperate evergreen forests in East Asia is still lacking.

The volcanic Jeju Island of South Korea is characterized by its high endemism, unique altitudinal zonation of vegetation, and untouched environments [19], and thus it was designated as a UNESCO Biosphere Reserve in 2002 and a World Heritage Site in 2007. The island is disjunctively located at the marginal edge of the distributional range of East Asian evergreen broad-leaved forests. The lowland zone of Jeju Island is covered with forests, dominated by warm temperate and subtropical evergreen broad-leaved plants [20]. These species commonly inhabit large ranges across East Asia, including South Korea, Japan, and China, but exhibit disjunctive distributions, with a heterogeneous boundary of habitat preferences [21]. Therefore, conserving the populations at the marginal edge of their range can be beneficial to the long-term survival of a species.

Quercus gilva Blume (Fagaceae) is a large, ecologically important tree of evergreen broad-leaved forests in East Asia [22]. Although Q. gilva is widely distributed in East Asian forests [23,24], its habitat is decreasing due to anthropogenic pressure. The main cause of habitat decrease is human-mediated disturbance, such as large-scale regional development [25] and logging [26]. The population of Jeju Island is extremely small (total: ca. 600 individuals; [27]) and distributed in a unique habitat, called Gotjawal, where the trees occur in an area made up of numerous fragmented rocks. This species is listed as Vulnerable (VU) in the Korea Red Data Book [28]. As of 2012, it has also been protected under the Endangered Species Act (ESA) within Korean law. Since tracking of intraspecific Conservation Units (CUs) is one of the most important tasks for the long-term conservation of a given species, a population genetic examination for Q. gilva was attempted using RAPD (Random Amplified Polymorphic DNA) [29] and ISSR (Inter Simple Sequence Repeat) [25] analysis. However, previous assessments have not been performed with other comparative populations, which could be a criterion for accurately recognizing their genetic status. From a recent conservation genetics point of view, providing information on the population's establishment history is becoming a fundamental step in long-term conservation [30-32].

Fossils and pollen grains could be utilized for unraveling evolutionary clues that contribute to present genetic diversity, but the situation is complicated by historically complex distribution changes [33,34]. However, such past data are largely absent in East Asia, because the area in which the evergreen forests appear to have been historically distributed is now in the sea. Given this, a technique such as Ecological Niche Modeling (ENM) is the only auxiliary way to reveal the historical distribution 
of a species [35]. ENM is useful in genetic studies to infer climate change-associated correlations between distribution shifts and genetic structure [36-38].

As has been observed in other warm temperate species in East Asia [5,6,39], the extant Jeju populations of $Q$. gilva are most closely related to those in Kyushu, Japan, which is geographically adjacent and has a similar establishment history. Therefore, we characterized the genetic compositions of the Q. gilva populations in Jeju Island, located at the disjunctive edge of their distribution range. The genetic diversity was compared to the Kyushu populations, regarded as long-term glacial refugia with a high genetic variability of East Asian warm temperate evergreen broad-leaved trees. The purposes of the present study are (1) to develop a high-resolution and cost-effective polymorphic microsatellite set so that researchers can continue periodic genetic monitoring, (2) to evaluate the evolutionary potential and conservation value of marginal-edge Jeju populations by inferring the history of population establishment, and (3) to provide conservation guidelines for the recovery and management of the threatened Jeju populations. The genetic diversity and structure were analyzed using 40 polymorphic microsatellite markers developed in this study through high-throughput sequencing data. ENM was also employed to examine historical distribution changes.

\section{Materials and Methods}

\subsection{Plant Material Sampling and DNA Extraction}

We collected a total of 158 leaf samples of Q. gilva from three populations in Jeju Island, Korea and three populations in Kyushu, Japan. Since Q. gilva is protected as an endangered species in Korea, we first requested permission from the Ministry of Environment and then proceeded with the material collection. We selected the trees with a diameter at breast height (DBH) of more than $20 \mathrm{~cm}$ while maintaining minimal intervals of more than $5 \mathrm{~m}$ between individuals. One leaf sample was collected per individual to minimize damage to the species. In Jeju populations, a total of 77 leaves, including 32 from Gueok-ri (k-GU), 27 from Jeoji-ri (k-JJ), and 18 from Seogwang-ri (k-SG), were obtained, with an average of 25.6. In the Kyushu populations, an average of 27 and total of 81 leaf samples were collected from Kitadake, Kumamoto Prefecture (j-GM; 23), and Aoidake (j-MY; 29) and Enodake (j-NB; 29) in Miyazaki Prefecture. Collected leaf samples were stored at $-80{ }^{\circ} \mathrm{C}$ in a deep freezer at the lab of Biological Education, Chonnam National University until use. Total genomic DNA was extracted from dried leaf samples using the DNeasy Plant mini kit (Qiagen, Seoul, Korea) following the manufacturer's instructions. The concentration of extracted DNA was determined using Nano-300 (Allsheng, Hangzhou, China), and diluted to $15 \mathrm{ng} / \mu \mathrm{L}$ to obtain the same concentration of template DNA in each sample.

\subsection{Loci Isolation for Microsatellite Markers' Development and Genotyping}

In order to develop polymorphic microsatellite markers for Q. gilva, we produced high-throughput sequencing data in a fresh leaf collected from Gueok-ri, Seogwipo-si, JeJu Island, Korea. A voucher specimen was deposited in the herbarium of Chonnam National University (BEC) (Voucher no. LeeQg20180502). A shotgun library construction for DNA sequencing was generated using the Illumina MiSeq platform (LAS, Seoul, Korea). According to the method of Cho et al. [40], we detected di-, tri-, or tetranucleotide motifs with flanking regions $>100 \mathrm{bp}$ and at least 10 , six, or four repeats, respectively, through SSR_pipeline v. 0.951 [41]. After acquiring reads containing microsatellites from this screening, we attempted a reference mapping of the total paired reads to each remaining sequence using Geneious R11.0.5 [42]. In the reference-mapped results, after discarding putative multicopy loci with exceptionally high coverage ( $>20$ reads), we used the final reads, showing the variation in length at the repeating site, no substitution of the site to produce the primer, and no additional insertion/deletion in the flanking region. Based on the final selected reads, we designed 54 primer pairs using Primer3 version 0.4.0 software [43] in the Geneious program according to the following parameters: primer size $18-22 \mathrm{bp}, \mathrm{Tm}$ (melting temperature) of $53-60{ }^{\circ} \mathrm{C}$, and GC content of $35-65 \%$. 
The forward primers added three sets of M13 tag sequences (5'-CACGACGTTGTAAACGAC- $3^{\prime}$, 5'-TGTGGAATT GTGAGCGG-3' ${ }^{\prime}$, and 5' -CTATAGGGCACGCGTGGT-3') with 6-FAM, VIC, and NED fluorescent dye, respectively.

To assess the polymorphisms for the designed microsatellite loci, we conducted a preliminary PCR analysis with 32 individuals from the Gueok-ri population. PCR amplification was performed with a Veriti 96-well thermal cycler (Applied Biosystems, Foster City, CA, USA) using $5 \mu \mathrm{L}$ volumes that were composed of $15 \mathrm{ng}$ of extracted DNA, $2.5 \mu \mathrm{L}$ Multiplex PCR Master Mix (Qiagen, Valencia, CA, USA), $0.01 \mu \mathrm{M}$ forward primer, $0.2 \mu \mathrm{M}$ reverse primer, and $0.1 \mu \mathrm{M}$ of the M13 primer (fluorescently labeled). PCR amplification was performed as follows: initial denaturation at $95^{\circ} \mathrm{C}$ for $15 \mathrm{~min}$; 35 cycles of denaturation at $95^{\circ} \mathrm{C}$ for $30 \mathrm{~s}$, annealing at $56^{\circ} \mathrm{C}$ for $1.5 \mathrm{~min}$, and extension at $72{ }^{\circ} \mathrm{C}$ for $1 \mathrm{~min}$; a final extension at $72{ }^{\circ} \mathrm{C}$ for $10 \mathrm{~min}$. The PCR products were diluted at $1: 30$, and $1 \mathrm{uL}$ was analyzed on an ABI 3730XL sequencer with GeneScan ${ }^{\mathrm{TM}}-500 \mathrm{LIZ}^{\mathrm{TM}}$ Size Standard (Applied Biosystems). Allele sizes and peaks for each sample were determined three times via Peak Scanner software 2 to minimize genotyping errors. We selected 46 polymorphic microsatellite loci with clear, strong peaks for each individual. Then, we tested the remaining 126 individuals from five populations according to the DNA extraction and PCR protocols described above.

\subsection{Statistical Data Analysis}

Before inferring the genotyping data, we estimated the null allele frequency using INEst (inbreeding/null allele estimation) software based on the individual inbreeding model (IIM), which calculates the null allele frequency regardless of the effect of inbreeding [44]. This analysis showed that six loci (Qrg009, Qrg013, Qrg026, Qrg030, Qrg036, and Qrg048) showed a null allele frequency of more than $5 \%$. Therefore, we used a total of 40 microsatellite markers, except for the six loci, for statistical analysis.

The summary genetics statistics were calculated at the population and pooled regional population levels. These included the number of alleles $\left(N_{\mathrm{A}}\right)$, the number of private alleles $\left(P_{\mathrm{A}}\right)$, the private allele rate $\left(P_{\text {riv }}\right)$, the mean expected heterozygosity $\left(H_{\mathrm{E}}\right)$, the mean observed heterozygosity $\left(H_{\mathrm{O}}\right)$, and the fixation index $\left(F_{\mathrm{IS}}\right)$, calculated using GenAlEx 6.5 [45]. The allele richness $\left(A_{\mathrm{R}}\right)$ and genetic differentiation among populations $\left(F_{\mathrm{ST}}\right)$ were determined by calculating the overall $F_{\mathrm{IS}}$ according to the method of Weir and Cockerham [46], using FSTAT 1.2 [47]. The statistical significance of $F_{\mathrm{ST}}$ was tested using the log-likelihood $(G)$-based exact test in FSTAT. To test for departures from Hardy-Weinberg equilibrium (HWE) and linkage equilibrium, we conducted exact tests based on a Markov chain method (1000 permutations), using GENEPOP 4.0 [48]. The possibility of recent bottleneck for population was detected using BOTTLENECK 1.2.02 [49] (1000 iterations). We utilized two models for evolution-a two-phase model (TPM; the proportion of the stepwise mutation model (SMM) in TPM $=0.000$, variance of the geometric distribution for TPM $=0.36)$, and a stepwise mutation model $(\mathrm{SMM})$ - in a BOTTLENECK analysis that included the Bayesian Wilcoxon signed-rank test, to evaluate departures from a 1:1 deficiency/excess ratio [50]. The possibility of population bottleneck was also estimated by a mode-shift test, which detects disruptions in the distribution of allelic frequencies [50].

To analyze the population structure, we used a Bayesian clustering approach implemented in STRUCTURE 2.3, as calculated from microsatellite markers [51], using 1,000,000 Markov Chain Monte Carlo (MCMC) iterations (100,000 burn-in, with admixture). The simulation used 20 iterations, with $K=1$ to $K=7$ clusters. The optimal number of clusters, $K$, was found via the $K$ method, using STRUCTURE HARVESTER [52]. CLUMPP v. 1.1.2 [53] with the Greedy algorithm was used to combine the membership coefficient matrices ( $Q$-matrices) from 1000 iterations for $K=2$, using random input orders.

To test for the presence of isolation-by-distance (IBD), we used Mantel tests in GenAlEx 6.5 [45] with 999 random permutations; this requires a correlation analysis between the pairwise $F_{\mathrm{ST}}$ values, and measurements of geographic distance between populations. To identify genetic boundaries between populations, we performed a barrier analysis [54] based on Monmonier's algorithm [55] 
with 1000 bootstrap matrices of pairwise $D_{\mathrm{A}}$ standard genetic distance [56] that were calculated by MICROSATELLITE ANALYZER (MSA) v. 4.05 [57]. The distance matrices were also used to construct a 50\% consensus tree by the Neighbor-Joining (N-J) method, as implemented in PHYLIP v. 3.68 [58]. To find the genetic structure of $Q$. gilva, a principal coordinate analysis (PCOA) was conducted by the covariance standardized approach of pairwise Nei's genetic distances in GenAlEx 6.5.

\subsection{Ecological Niche Modeling}

We modeled the present and past (during LGM) potential distributions of Quercus gilva using Maxent 3.4.1 [59]. Occurrence data for this species included sample localities from our study as well as published data [27] and GBIF data with preserved specimens [60]. We obtained 242 occurrence data points and the occurrence data were spatially rarefied using SDMtoolbox 2.4 [61] to reduce bias in developing the distribution model. Two occurrence points of Korean Peninsula (inland) and Toyama Prefecture in Japan were excluded because they were estimated to be distributed in uncertain and inappropriate climate zones. A total of 97 occurrence data points were finally used in ENM. We obtained 19 bioclimatic variables (Online Resource 2) for the present and LGM from Climatologies at High Resolution for the Earth's Land Surface Areas (CHELSA, http://chelsa-climate.org/; [62]). We obtained elevation data for the present-the Global Multi-resolution Terrain Elevation Data (GMTED2010) dataset [63]—from the USGS EROS Archive (https://www.usgs.gov/land-resources/ eros/coastal-changes-and-impacts/gmted2010), and for the LGM from CHELSA. To reconstruct the historical distributions, we utilized three past climate models for LGM: the Community Climate System Model (CCSM4; [64]), the Earth System Model based on the Model for Interdisciplinary Research on Climate (MIROC-ESM; [65]), and the Max Planck Institute for Meteorology Earth System model (MPI-ESM-P). We selected one of the climate variables and elevation data sharing a high Spearman correlation efficient (>0.7) by using SDMtoolbox 2.4 [61], in order to avoid multicollinearity problems. Therefore, 7 of 20 variables were used in ENM. To reduce the effects of uncertainty in the historical climate models, we averaged the historical distributions that were based on each of the three climate models. The climate data, for $20-37^{\circ} \mathrm{N}$ and $115-145^{\circ} \mathrm{E}$ (30 arcsecond resolution), were extracted using ArcGIS 10.5 (ESRI 2017). Maxent runs were performed in batch mode with these settings: create response curves, conduct jackknife tests, use 20 replicates, generate logistic output, select random seeds, and we used 10,000 background points and 1,000 iterations.

\section{Results}

\subsection{Development of Polymorphic Microsatellite Markers}

In total, 11,957,206 reads were generated by Illumina paired-end sequencing (Short Read Archive accession number: PRJNA649602). The total number of reads containing microsatellites identified through the SSR-pipeline was 100,849 reads, including 55,084 reads with dinucleotide motifs, 41,037 reads with trinucleotide motifs, and 4,728 reads with tetranucleotide motifs. Of these, the di-, tri-, and tetranucleotide motifs with planking areas of $>100 \mathrm{bp}$ and having repeating units of at least 12,6 , and 6, respectively, were 29,058 reads, 21,424 reads, and 2,562 reads.

As a result of applying 54 designed microsatellite loci to 32 individuals of Q. gilva from Gueok-ri populations in Korea, 46 polymorphic microsatellite markers with clear and strong peaks for each allele were selected (Table 1). Regarding the results of the genetic diversity analysis, a total of 385 alleles were detected in 46 microsatellite loci across all samples. The number of alleles $\left(N_{\mathrm{A}}\right)$ per locus ranged from 2 to 19, with an average of 8.370 alleles per locus. Values for observed heterozygosity $\left(H_{\mathrm{O}}\right)$ and expected heterozygosity $\left(H_{\mathrm{E}}\right)$ ranged from 0.044 to 0.918 (mean: 0.616$)$ and from 0.067 to 0.899 (mean: $0.664)$, respectively (Table 2$)$. The inbreeding coefficient $\left(F_{\mathrm{IS}}\right)$ for each locus ranged from -0.135 to 0.669. The null allele frequency identified by INEst software ranged from 0.0018 to 0.2774 . Comparing the genetic diversity $\left(N_{\mathrm{A}}\right.$ and $\left.H_{\mathrm{E}}\right)$ by the locus of di-, tri-, and tetranucleotide motifs, the results were 
higher in loci with dinucleotide motifs (mean $\left.N_{\mathrm{A}}=11.125, H_{\mathrm{E}}=0.784\right)$ than with tri- (mean $N_{\mathrm{A}}=5.571$, $H_{\mathrm{E}}=0.527$ ) or tetranucleotide motifs (mean $N_{\mathrm{A}}=5.000, H_{\mathrm{E}}=0.547$ ) (Figure 1 ).

Table 1. Characterization of six multiplexes of 46 microsatellite loci for Quercus gilva.

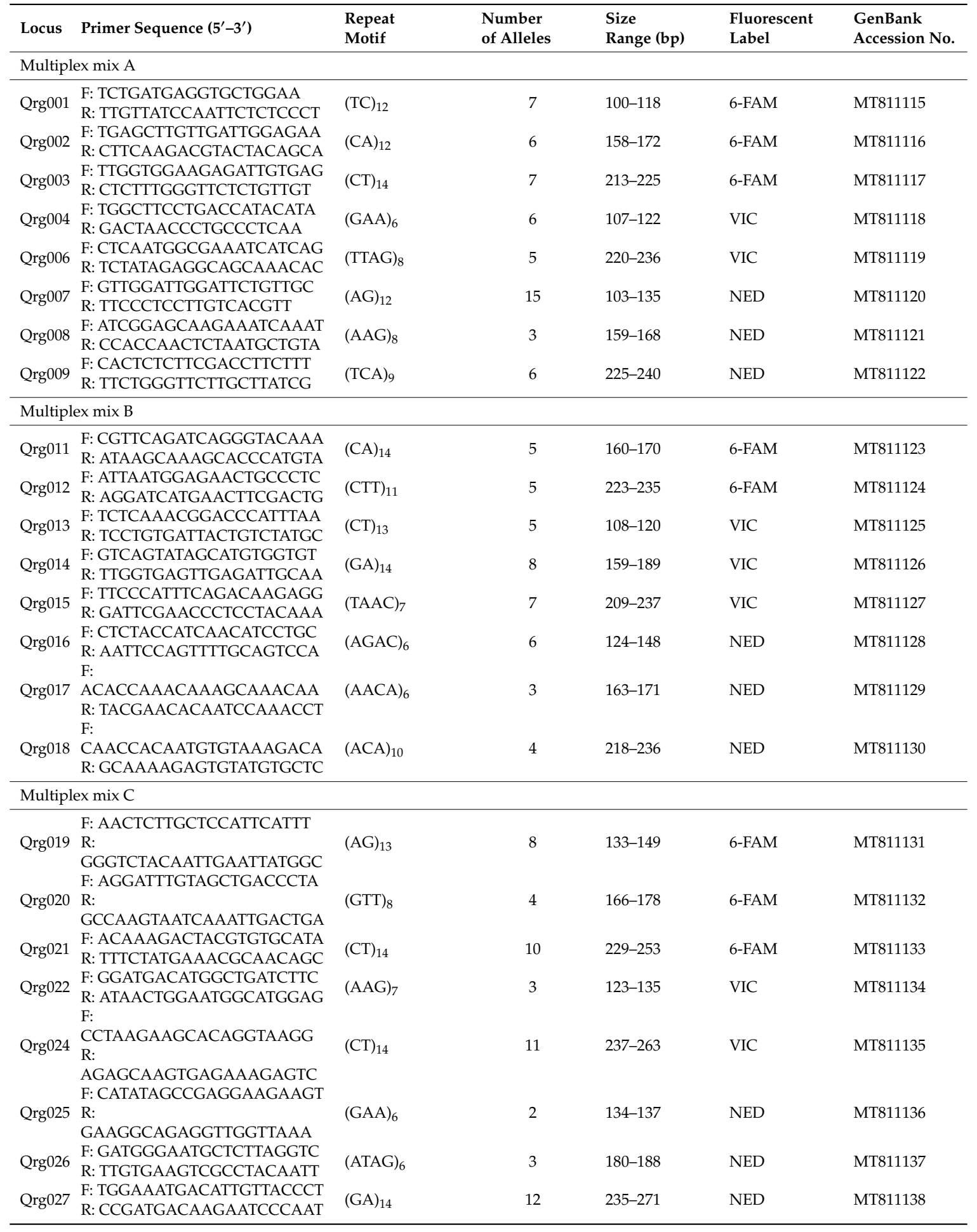


Table 1. Cont.

\begin{tabular}{|c|c|c|c|c|c|c|}
\hline Locus & Primer Sequence $\left(5^{\prime}-3^{\prime}\right)$ & $\begin{array}{l}\text { Repeat } \\
\text { Motif }\end{array}$ & $\begin{array}{l}\text { Number } \\
\text { of Alleles }\end{array}$ & $\begin{array}{l}\text { Size } \\
\text { Range (bp) }\end{array}$ & $\begin{array}{l}\text { Fluorescent } \\
\text { Label }\end{array}$ & $\begin{array}{l}\text { GenBank } \\
\text { Accession No. }\end{array}$ \\
\hline \multicolumn{7}{|c|}{ Multiplex mix D } \\
\hline Qrg028 & $\begin{array}{l}\text { F: TAAAGGAGTGCATGGTGAAA } \\
\text { R: AGTGAAGCCTCTTTCCTAGA }\end{array}$ & $(\mathrm{CT})_{13}$ & 9 & 127-147 & 6-FAM & MT811139 \\
\hline Qrg029 & $\begin{array}{l}\text { F: AAGATAACTGCACGCTTGTA } \\
\text { R: TCAGAAATCGCTCATACCTG }\end{array}$ & $(\mathrm{TG})_{13}$ & 7 & 184-196 & 6-FAM & MT811140 \\
\hline Qrg030 & $\begin{array}{l}\text { F: CTATTCATGGACTCCTCTGT } \\
\text { R: AATTGCAAGGCCTTAGAACT }\end{array}$ & $(\mathrm{AG})_{15}$ & 7 & $235-249$ & 6-FAM & MT811141 \\
\hline Qrg031 & $\begin{array}{l}\text { F: GGTTAGGGCTCTTTCCAAAT } \\
\text { R: CTCTCCCTTTCTTTCACTGT }\end{array}$ & $(\mathrm{GA})_{13}$ & 8 & 131-145 & VIC & MT811142 \\
\hline Qrg033 & $\begin{array}{l}\text { F: TCTTGCCAATCTAAATCCCA } \\
\text { R: TGCATGATACAGAAACACCA } \\
\text { F: GGACATCTACAGCCTACAAA }\end{array}$ & $(\mathrm{AAGA})_{7}$ & 2 & $239-247$ & VIC & MT811143 \\
\hline Qrg034 & $\begin{array}{l}\text { R: } \\
\text { CGCAGACCAAATATCATTCTC }\end{array}$ & $(\mathrm{CT})_{12}$ & 12 & $143-173$ & NED & MT811144 \\
\hline Qrg036 & $\begin{array}{l}\text { F: TAACTTTGTTCTCGCCTGA } \\
\text { R: AATGTAGAGCCTGTTTGCAT }\end{array}$ & $(\mathrm{GA})_{13}$ & 7 & $239-259$ & NED & MT811145 \\
\hline \multicolumn{7}{|c|}{ Multiplex mix E } \\
\hline Qrg037 & $\begin{array}{l}\text { F: } \\
\text { TTCGAGATAGGACAGAGGAG } \\
\text { R: TGTGTTTGATTAGCGGAGAA }\end{array}$ & $(\mathrm{AAGA})_{8}$ & 5 & 128-144 & 6-FAM & MT811146 \\
\hline Qrg038 & $\begin{array}{l}\text { F: TGGCTATGATAATTGTGGGT } \\
\text { R: CTCAACCCTGTTATCTCACC } \\
\text { F: AAAGTGGATTTGCAGCCTAA }\end{array}$ & $(\mathrm{GA})_{17}$ & 8 & 182-204 & 6-FAM & MT811147 \\
\hline Qrg039 & $\begin{array}{l}\text { R: } \\
\text { GACAATGGAGAAGGGACAAT }\end{array}$ & $(\mathrm{TC})_{14}$ & 6 & $244-260$ & 6-FAM & MT811148 \\
\hline Qrg040 & $\begin{array}{l}\text { F: GCATTTCTCTCTCTGGTTCA } \\
\text { R: AAGTACCCTCCATCTACGTT }\end{array}$ & $(\mathrm{AAG})_{6}$ & 3 & $128-146$ & VIC & MT811149 \\
\hline Qrg041 & $\begin{array}{l}\text { F: CTTCCTCGTCAATAGTCCAC } \\
\text { R: AGTGAGTTTGATACGCTTGT }\end{array}$ & $(\mathrm{AAG})_{12}$ & 9 & $186-228$ & VIC & MT811150 \\
\hline Qrg042 & $\begin{array}{l}\text { F: CCCACACATTATACCACGAA } \\
\text { R: CTACTAACAACCGCAACTCT }\end{array}$ & $(\mathrm{AG})_{17}$ & 8 & $227-253$ & VIC & MT811151 \\
\hline Qrg043 & $\begin{array}{l}\text { F: CATACATCCTAGTGCAGCAG } \\
\text { R: GGTAGCTCAAGTTCACAGTT }\end{array}$ & $(\mathrm{CAA})_{6}$ & 2 & 149-155 & NED & MT811152 \\
\hline \multicolumn{7}{|c|}{ Multiplex mix F } \\
\hline Qrg046 & $\begin{array}{l}\text { F: CTGCCCCTAACTAATCTGTT } \\
\text { R: GTAGATGATGAGGTTGTGGG }\end{array}$ & $(\mathrm{TGT})_{6}$ & 2 & $149-152$ & 6-FAM & MT811153 \\
\hline Qrg047 & $\begin{array}{l}\text { F: AGACCAGTAGATGCTTCAAA } \\
\text { R: ATTCATGACCCTCCTTCTCA }\end{array}$ & $(\mathrm{AAG})_{9}$ & 3 & 208-217 & 6-FAM & MT811154 \\
\hline Qrg048 & $\begin{array}{l}\text { F: TCCATCGTCAACAAAGGATT } \\
\text { R: AACCAGTTCTCACTCTCTCT }\end{array}$ & $(\mathrm{AG})_{17}$ & 7 & $235-269$ & 6-FAM & MT811155 \\
\hline Qrg049 & $\begin{array}{l}\text { F: CAACTACTGTAGCCTTGTGT } \\
\text { R: TATGCCTCCAGTGTACTACA }\end{array}$ & $(\mathrm{CA})_{12}$ & 7 & $146-166$ & VIC & MT811156 \\
\hline Qrg050 & $\begin{array}{l}\text { F: GGGACCATAGCAGTGTTAAT } \\
\text { R: AGCCCTCCCTTATTATTCC } \\
\text { F: CTCCTCTTGGCTATGACATC }\end{array}$ & $(\mathrm{TC})_{21}$ & 8 & $192-216$ & VIC & MT811157 \\
\hline Qrg051 & $\begin{array}{l}\text { R: } \\
\text { TCTTGTTTGAGGAAGTTGACA } \\
\text { F: ACTTGTAACTAACCTGGCTC }\end{array}$ & $(\mathrm{TTC})_{14}$ & 10 & 235-259 & VIC & MT811158 \\
\hline Qrg052 & $\begin{array}{l}\text { R: } \\
\text { CTAGGAGGATGAAATGGCAA }\end{array}$ & $(\mathrm{CTAA})_{8}$ & 4 & 150-162 & NED & MT811159 \\
\hline Qrg053 & $\begin{array}{l}\text { F: TGACAGTACATGGTAAAGCT } \\
\text { R: TTCTTGGTCTTGAATGAGGA }\end{array}$ & $(\mathrm{CT})_{14}$ & 7 & $204-228$ & NED & MT811160 \\
\hline
\end{tabular}

Table 2. Genetic parameters for 46 microsatellite loci across all samples developed for Quercus gilva.

\begin{tabular}{cccccccccc}
\hline Locus & $\boldsymbol{N}_{\boldsymbol{A}}$ & $\boldsymbol{H}_{\mathbf{O}}$ & $\boldsymbol{H}_{\mathrm{E}}$ & Null & Locus & $\boldsymbol{N}_{\boldsymbol{A}}$ & $\boldsymbol{H}_{\mathbf{O}}$ & $\boldsymbol{H}_{\mathrm{E}}$ & Null \\
\hline Qrg001 & 8 & 0.703 & 0.619 & 0.0020 & Qrg027 & 16 & 0.829 & 0.865 & 0.0031 \\
Qrg002 & 10 & 0.741 & 0.755 & 0.0053 & Qrg028 & 10 & 0.842 & 0.820 & 0.0018 \\
Qrg003 & 7 & 0.741 & 0.794 & 0.0112 & Qrg029 & 8 & 0.677 & 0.743 & 0.0275 \\
Qrg004 & 7 & 0.778 & 0.786 & 0.0057 & Qrg030 & 9 & 0.253 & 0.765 & $0.2774 *$ \\
Qrg006 & 6 & 0.772 & 0.763 & 0.0033 & Qrg031 & 10 & 0.810 & 0.841 & 0.0091 \\
Qrg007 & 18 & 0.918 & 0.899 & 0.0012 & Qrg033 & 3 & 0.222 & 0.209 & 0.0048 \\
Qrg008 & 4 & 0.361 & 0.366 & 0.0058 & Qrg034 & 16 & 0.867 & 0.885 & 0.0038 \\
\hline
\end{tabular}


Table 2. Cont.

\begin{tabular}{cccccccccc}
\hline Locus & $\boldsymbol{N}_{\boldsymbol{A}}$ & $\boldsymbol{H}_{\mathbf{O}}$ & $\boldsymbol{H}_{\mathrm{E}}$ & Null & Locus & $\boldsymbol{N}_{\boldsymbol{A}}$ & $\boldsymbol{H}_{\mathbf{O}}$ & $\boldsymbol{H}_{\mathrm{E}}$ & Null \\
\hline Qrg009 & 8 & 0.570 & 0.748 & $0.0868^{*}$ & Qrg036 & 9 & 0.627 & 0.800 & $0.0910^{*}$ \\
Qrg011 & 6 & 0.684 & 0.745 & 0.0071 & Qrg037 & 5 & 0.696 & 0.738 & 0.0118 \\
Qrg012 & 7 & 0.759 & 0.756 & 0.0026 & Qrg038 & 13 & 0.759 & 0.794 & 0.0076 \\
Qrg013 & 8 & 0.513 & 0.657 & $0.0728^{*}$ & Qrg039 & 6 & 0.753 & 0.731 & 0.0035 \\
Qrg014 & 11 & 0.861 & 0.835 & 0.0016 & Qrg040 & 3 & 0.468 & 0.539 & 0.0218 \\
Qrg015 & 7 & 0.620 & 0.671 & 0.0073 & Qrg041 & 13 & 0.823 & 0.808 & 0.0025 \\
Qrg016 & 6 & 0.608 & 0.622 & 0.0044 & Qrg042 & 14 & 0.734 & 0.805 & 0.0204 \\
Qrg017 & 5 & 0.589 & 0.597 & 0.0117 & Qrg043 & 3 & 0.133 & 0.131 & 0.0058 \\
Qrg018 & 6 & 0.532 & 0.631 & 0.0464 & Qrg046 & 3 & 0.348 & 0.384 & 0.0192 \\
Qrg019 & 10 & 0.759 & 0.824 & 0.0121 & Qrg047 & 4 & 0.475 & 0.496 & 0.0067 \\
Qrg020 & 5 & 0.633 & 0.674 & 0.0050 & Qrg048 & 12 & 0.595 & 0.808 & $0.0977 *$ \\
Qrg021 & 19 & 0.861 & 0.886 & 0.0062 & Qrg049 & 10 & 0.430 & 0.505 & 0.0353 \\
Qrg022 & 3 & 0.165 & 0.179 & 0.0099 & Qrg050 & 14 & 0.791 & 0.819 & 0.0044 \\
Qrg024 & 13 & 0.741 & 0.857 & 0.0355 & Qrg051 & 10 & 0.810 & 0.814 & 0.0036 \\
Qrg025 & 2 & 0.044 & 0.067 & 0.0316 & Qrg052 & 4 & 0.551 & 0.572 & 0.0106 \\
Qrg026 & 4 & 0.139 & 0.203 & $0.0607 *$ & Qrg053 & 10 & 0.741 & 0.756 & 0.0029 \\
\hline
\end{tabular}

$N_{A}$, number of alleles; $H_{\mathrm{O}}$, observed heterozygosity number of alleles; $H_{\mathrm{E}}$, expected heterozygosity; Null, null allele frequency estimate. * indicates that the frequency of the null allele exceeds $5 \%$.

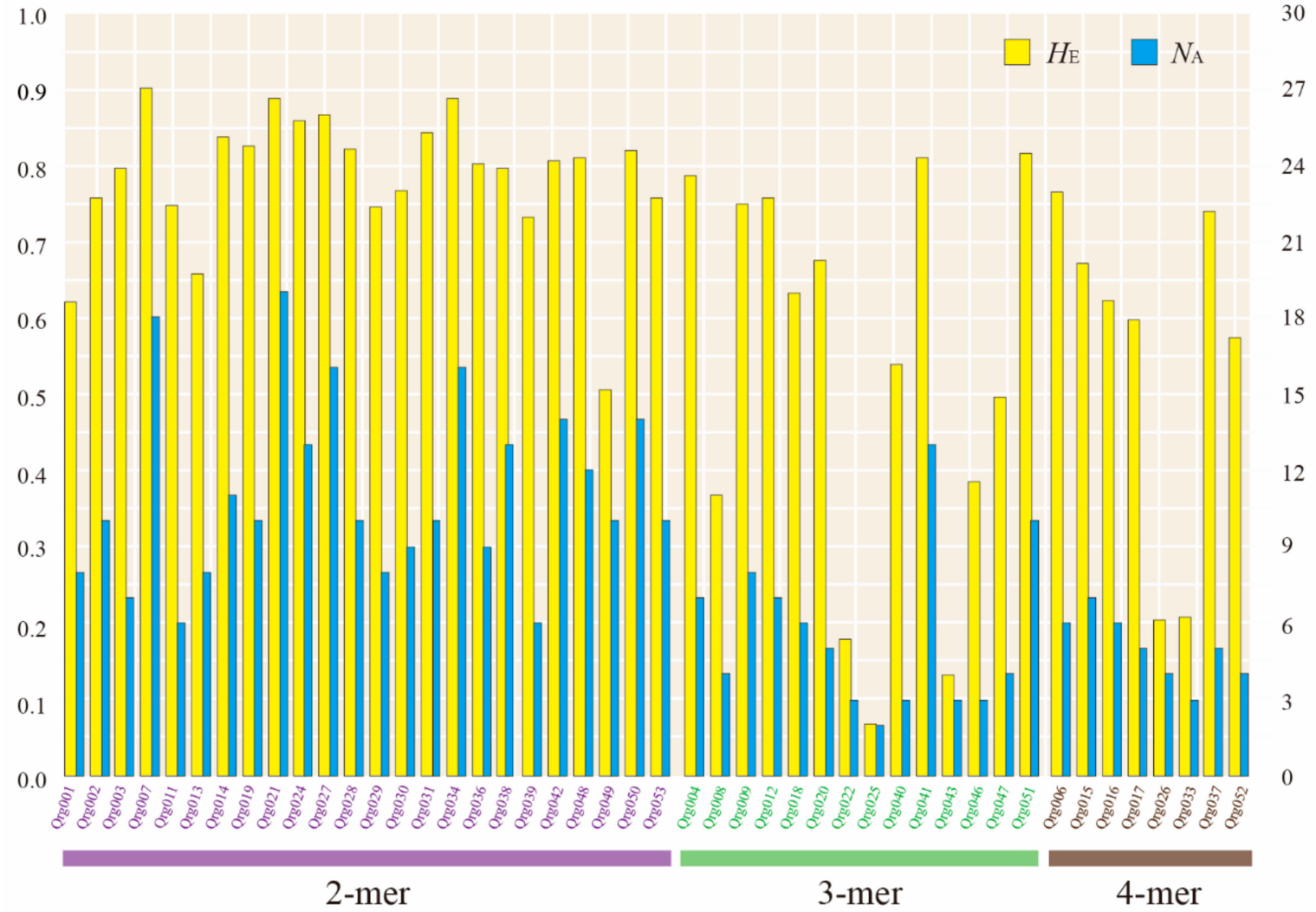

Figure 1. Comparing genetic diversity $\left(N_{\mathrm{A}}\right.$ and $\left.H_{\mathrm{E}}\right)$ by locus with di-, tri-, and tetranucleotide motifs. Genetic diversity is based on the allele frequency of six populations of Quercus gilva using 46 microsatellite loci.

All the developed markers were deposited in in the National Center for Biotechnology Information's GenBank database (Table 1). As a result, a cost-effective set of 46 polymorphic microsatellite markers with high resolutions has been successfully developed. These markers will be useful for conserving genetic resources through periodical monitoring management, creating a seed 
genogram, cloning detection, and postrestoration assessments in the endangered Jeju populations of Q. gilva.

\subsection{Genetic Diversity}

Genetic diversity parameters, evaluated at the population and pooled regional population levels for all 158 individuals of Q. gilva, are shown in Table 3. In total, 335 alleles were amplified from 40 microsatellite loci, with an average of 8.4 alleles per locus. They ranged from a minimum of two (Qrg025) to a maximum of 19 (Qrg021). Among the six Q. gilva populations, the levels of genetic diversity showed no noticeable difference; the number of alleles ranged from 224 to 261 (mean of 244.7); $H_{\mathrm{E}}$ ranged from $0.615(\mathrm{j}-\mathrm{NB})$ to 0.651 (k-SG) (mean of 0.639); $A_{\mathrm{R}}$ ranged from 5.201 (j-NB) to 5.940 (j-MY) (mean of 5.726); $P_{\mathrm{A}}$ ranged from 4 (k-JJ and j-NB) to 11 (k-GU) (mean of 7); $F_{\mathrm{IS}}$ ranged from -0.024 (k-GU) to 0.043 (k-SG) (mean of 0.007). The k-SG population had the highest genetic diversity values, while the $\mathrm{j}-\mathrm{NB}$ population had the lowest $\left(H_{\mathrm{E}}, A_{\mathrm{R}}\right)$. In the comparison between the Jeju and Kyushu populations, the levels of genetic diversity were almost equivalent, showing only a slight difference in degree depending on the parameters (Table 3). The BOTTLENECK analysis (Wilcoxon tests) showed no significant bottleneck effects across all populations under a TPM and SMM $(p>0.05)$, as well as a mode shift (Table 4). 
Table 3. Summary statistics of genetic diversity for six populations based on 40 microsatellite loci of Quercus gilva.

\begin{tabular}{|c|c|c|c|c|c|c|c|c|c|c|c|}
\hline ID & Location & Coordinates & $E_{\mathrm{V}}$ & $N$ & $N_{\mathrm{A}}$ & $A_{\mathrm{R}}$ & $P_{\mathrm{A}}$ & $P_{\text {riv }}$ & $H_{\mathrm{O}}(\mathrm{SE})$ & $H_{\mathrm{E}}(\mathrm{SE})$ & $F_{\text {IS }}$ \\
\hline \multicolumn{12}{|l|}{ Jeju Island } \\
\hline k-GU & $\begin{array}{l}\text { Gueok-ri, } \\
\text { Daejeong-eup, Jeju }\end{array}$ & $\begin{array}{l}33^{\circ} 18^{\prime} 8.21^{\prime \prime} \mathrm{N} \\
126^{\circ} 16^{\prime} 36.59^{\prime \prime} \mathrm{E}\end{array}$ & 136 & 32 & 254 & 5.729 & 11 & 0.043 & $\begin{array}{c}0.660 \\
(0.037)\end{array}$ & $\begin{array}{c}0.645 \\
(0.033)\end{array}$ & - \\
\hline $\mathrm{k}-\mathrm{JJ}$ & $\begin{array}{l}\text { Jeoji-ri, } \\
\text { Hangyeong-myeon, } \\
\text { Jeju }\end{array}$ & $\begin{array}{l}33^{\circ} 18^{\prime} 45.36^{\prime \prime} \mathrm{N} \\
126^{\circ} 17^{\prime} 3.76^{\prime \prime} \mathrm{E}\end{array}$ & 168 & 27 & 254 & 5.905 & 4 & 0.016 & $\begin{array}{c}0.656 \\
(0.040)\end{array}$ & $\begin{array}{c}0.640 \\
(0.035)\end{array}$ & 0.003 \\
\hline k-SG & $\begin{array}{l}\text { Seogwang-ri, } \\
\text { Andeok-myeon, Jeju }\end{array}$ & $\begin{array}{l}33^{\circ} 17^{\prime} 57.47^{\prime \prime} \mathrm{N} \\
126^{\circ} 18^{\prime} 59.97^{\prime \prime} \mathrm{E}\end{array}$ & 201 & 18 & 237 & 5.925 & 8 & 0.034 & $\begin{array}{c}0.639 \\
(0.039)\end{array}$ & $\begin{array}{c}0.651 \\
(0.033)\end{array}$ & 0.043 \\
\hline Mean & & & 168.3 & 25.6 & 248.3 & 5.853 & 7.7 & 0.031 & 0.652 & 0.645 & 0.007 \\
\hline \multicolumn{3}{|c|}{ Pooled populations } & & 77 & 301 & 7.525 & 33 & 0.110 & 0.641 & 0.657 & 0.018 \\
\hline \multicolumn{12}{|l|}{ Kyushu } \\
\hline j-GM & $\begin{array}{l}\text { Kuma-gun, } \\
\text { Kumamoto } \\
\text { Prefecture }\end{array}$ & $\begin{array}{l}32^{\circ} 17^{\prime} 39.5^{\prime \prime} \mathrm{N} \\
130^{\circ} 52^{\prime} 17.6^{\prime \prime} \mathrm{E}\end{array}$ & 485 & 23 & 238 & 5.656 & 5 & 0.021 & $\begin{array}{c}0.638 \\
(0.039)\end{array}$ & $\begin{array}{c}0.634 \\
(0.036)\end{array}$ & -0.005 \\
\hline $\mathrm{j}-\mathrm{MY}$ & $\begin{array}{l}\text { Miyakonojo-shi, } \\
\text { Miyazaki Prefecture }\end{array}$ & $\begin{array}{l}31^{\circ} 50^{\prime} 55.7^{\prime \prime} \mathrm{N} \\
131^{\circ} 13^{\prime} 30.4^{\prime \prime} \mathrm{E}\end{array}$ & 230 & 29 & 261 & 5.940 & 10 & 0.038 & $\begin{array}{c}0.636 \\
(0.034)\end{array}$ & $\begin{array}{c}0.647 \\
(0.035)\end{array}$ & 0.003 \\
\hline $\mathrm{j}-\mathrm{NB}$ & $\begin{array}{l}\text { Nobeoka-shi, } \\
\text { Mivazaki Prefecture }\end{array}$ & $\begin{array}{l}32^{\circ} 39^{\prime} 15.8^{\prime \prime} \mathrm{N}, \\
131^{\circ} 41^{\prime} 14.3^{\prime \prime} \mathrm{E}\end{array}$ & 38 & 29 & 224 & 5.201 & 4 & 0.018 & $\begin{array}{c}0.613 \\
(0.043)\end{array}$ & $\begin{array}{c}0.615 \\
(0.038)\end{array}$ & 0.023 \\
\hline \multirow{2}{*}{\multicolumn{3}{|c|}{$\begin{array}{l}\text { Mean } \\
\text { Pooled populations }\end{array}$}} & 251 & 27 & 241 & 5.600 & 6.3 & 0.026 & 0.629 & 0.632 & 0.007 \\
\hline & & & & 81 & 302 & 7.503 & 34 & 0.113 & 0.628 & 0.648 & 0.015 \\
\hline
\end{tabular}

$\overline{E_{\mathrm{V}}}$, elevation of sampling site (meter); $N$, number of individuals; $N_{\mathrm{A}}$, number of alleles; $A_{\mathrm{R}}$, allelic richness; $P_{\mathrm{A}}$, number of private alleles; $P_{\text {riv }}$, private allelic rate; $H_{\mathrm{O}}$, observed heterozygosity number of alleles; $H_{\mathrm{E}}$, expected heterozygosity; $\mathrm{SE}$, standard error; $F_{\mathrm{IS}}$, inbreeding coefficient. 
Table 4. Probability of a bottleneck estimated using the program BOTTLENECK for six populations of Quercus gilva, based on the two-phase model (TPM) or stepwise mutation model (SMM).

\begin{tabular}{cccc}
\hline \multirow{2}{*}{ Population } & \multicolumn{2}{c}{ Wilcoxon Test } & \multirow{2}{*}{ Mode Shift } \\
\cline { 2 - 3 } & TPM & SMM & \\
\hline Jeju Island & & & No \\
\hline k-GU & 0.476153 & 0.988818 & No \\
k-JJ & 0.465576 & 0.991747 & No \\
k-SG & 0.294988 & 0.925049 & \\
\hline Kyushu & & & No \\
\hline j-GM & 0.383349 & 0.974584 & No \\
j-MY & 0.292696 & 0.982035 & No \\
j-NB & 0.135276 & 0.765987 &
\end{tabular}

\subsection{Population Structure}

To infer the population structure of Q. gilva, we performed STRUCTURE, N-J phylogeny, and PCoA analysis with 40 microsatellite loci. The results clearly demonstrated that the Jeju and Kyushu regions are genetically distinct. The STRUCTURE analysis showed that the optimal $K$-value was 2 for $\Delta K=199.678$ and the second fit value was 4 for $\Delta K=6.319$. At $K=2$, a strong genetic structure was found among populations, divided clearly into two regions (Figures 2 and 3). In terms of neighbor-joining criteria, the sampled populations of Q. gilva were clearly divided into two clusters (Jeju and Kyushu), in concordance with the clustering results obtained by STRUCTURE (Figure 4). The principal coordinate analysis (PCoA) results revealed a population structure that was in accordance with the STRUCTURE and N-J phylogeny analysis (Figure 5). The first two coordinates explained 7.32\% $\left(4.12 \%\right.$ for axis 1 and $3.20 \%$ for axis 2 ) of the total genetic variation. Based on pairwise $F_{\mathrm{ST}}$, the barrier analyses identified a strong barrier between the Jeju and Kyushu regions (Figure 2). Although the $F_{\mathrm{ST}}$ values of pairwise comparisons among the six populations showed a numerically low overall genetic differentiation, with a $F_{\mathrm{ST}}$ of 0.029 with 95 and $99 \%$ confidence intervals of $0.024-0.034$ and $0.022-0.036$, respectively, it was significant at all loci $(p<0.001)$. This differentiation was also seen between populations within Jeju Island (mean 0.010, with 95 and $99 \%$ confidence intervals of $0.005-0.017$ and $0.003-0.019, p<0.001$ ), and within populations of Kyushu (mean 0.021, with 95 and 99\% confidence intervals of $0.015-0.027$ and $0.013-0.029, p<0.001$ ). Therefore, the fact that the highest value of genetic differentiation is from the overall population means that it results from a difference between Jeju Island and Kyushu (Figure 6b). Additionally, isolation by distance (IBD) analysis, as determined by Mantel test, showed a significant correlation between genetic and geographic distance among populations $\left(R^{2}\right.$ $=0.7611, p=0.025)$ (Figure 6a). 


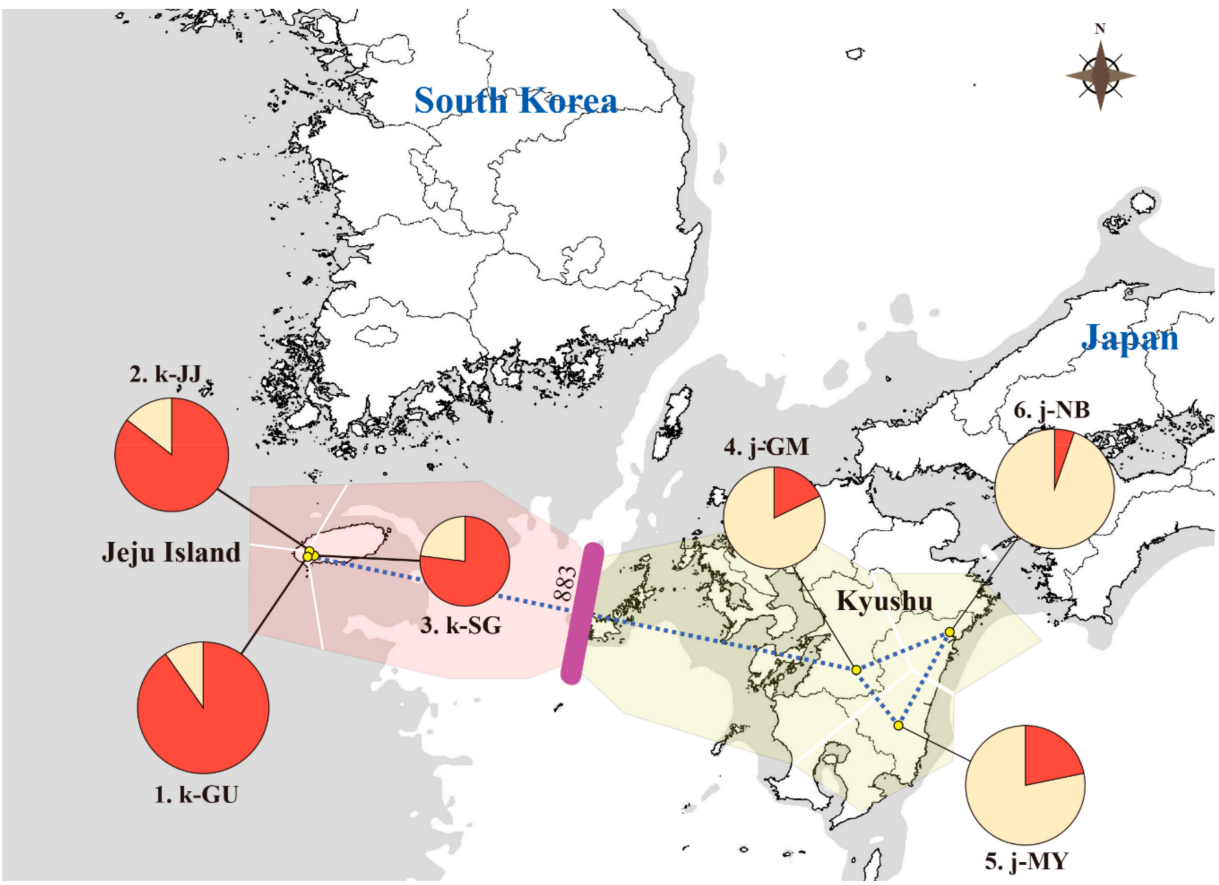

Figure 2. Genetic composition and a genetic barrier of Quercus gilva geographic populations using 40 microsatellite loci. Genetic composition is based on STRUCTURE clustering results $(K=2)$. The genetic barrier is marked with a thick purple line, estimated by BARRIER. The gray shading represents exposed coastal areas and sea basins during times of glacially induced alterations in sea levels during the Late Pleistocene.

(a)

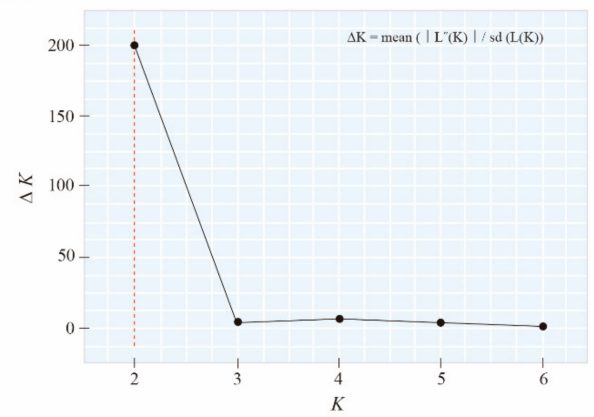

(b)

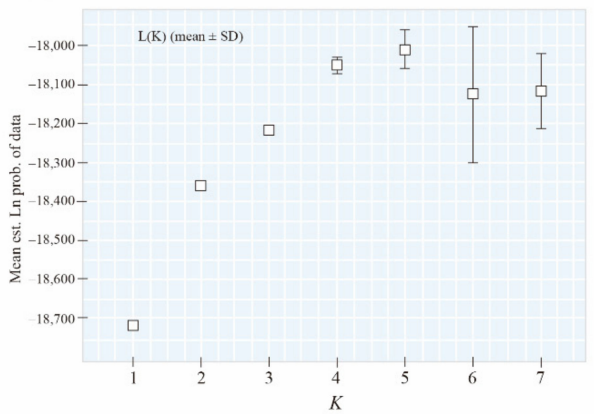

(c)

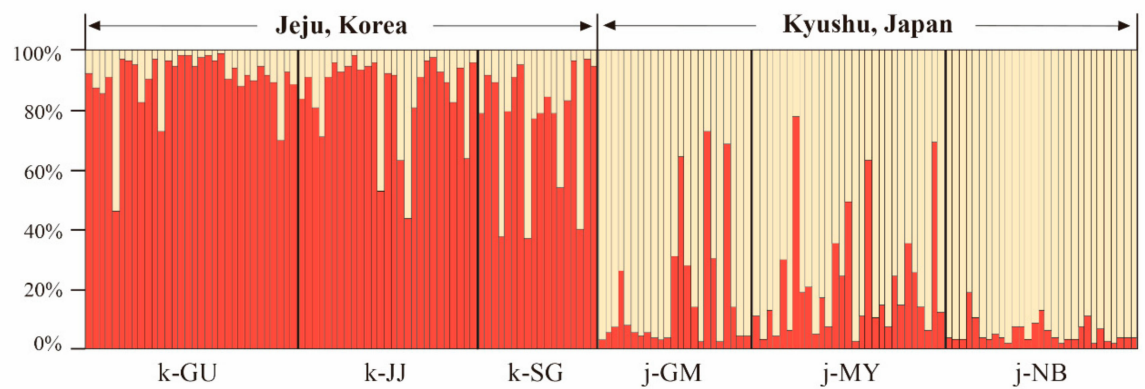

Figure 3. Plots generated in STRUCTURE Harvester (a) Evanno's delta K statistic; (b) the mean log-likelihood of the data $\mathrm{L}(\mathrm{K})$. Genetic structure of Quercus gilva populations based on Bayesian assignment tests performed in STRUCTURE. (c) Genetic structural plot of Q. gilva populations at $K=2$. Each individual is represented by a single vertical line that represents the individual's estimated membership fractions in these two clusters. 


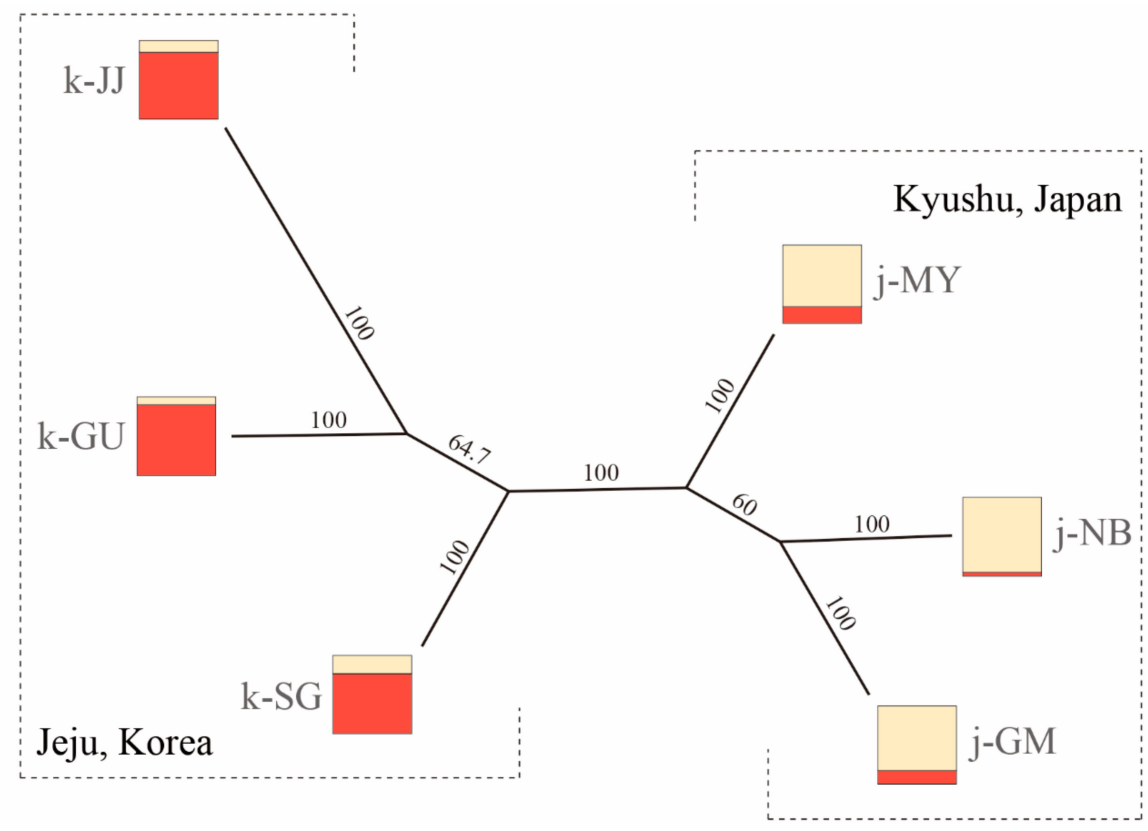

Figure 4. Neighbor-joining (N-J) tree based on $F_{\text {st }}$ genetic distance among populations. Figures in tree branches are percentage bootstrap values estimated from 1000 reiterations. The square marks indicate the overall genotype assignment for each population to particular genetic clusters based on STRUCTURE analysis.

Principal Coordinates (PCoA)

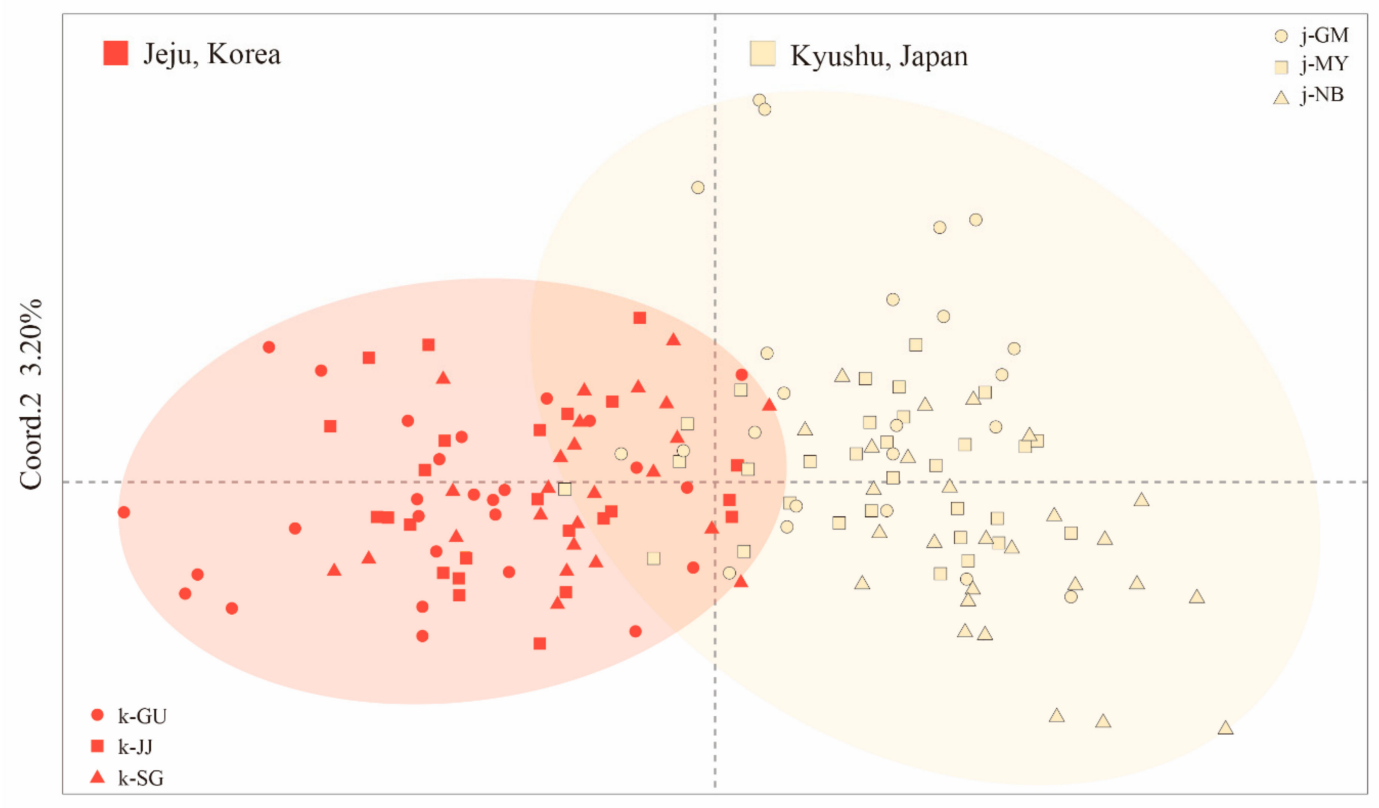

Coord. $14.12 \%$

Figure 5. Principal coordinates analysis based on Nei's genetic distance calculated from the allele frequencies of the 158 individuals for Quercus gilva. The orange symbols indicate individuals of Jeju region, and the yellow ones indicate Kyushu region. Six subgroups indicate each populations of Q. gilva. 
(a)

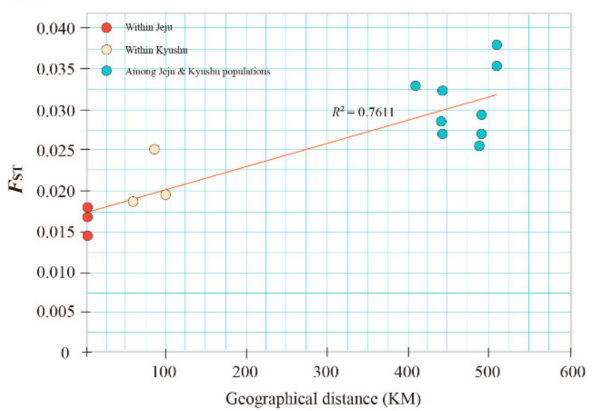

(b)

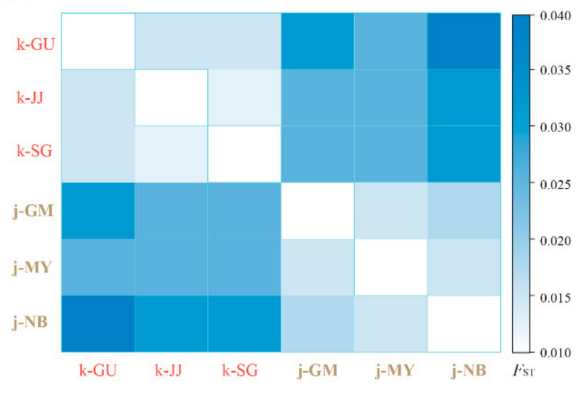

Figure 6. The genetic differentiation for the six populations of Quercus gilva. (a) Mantel tests between $F_{S T}$ values and geographical distance among populations; (b) distance matrix of pairwise $F_{S T}$ between populations.

\subsection{Ecological Niche Modeling}

The ENM of Q. gilva (Figure 7) had a high average AUC (area under the curve) (0.899), supporting its predictive power. The most important variable was bio_02 (mean diurnal range; $55.8 \%$ ), followed by bio_12 (annual precipitation; 14.6\%) and bio_15 (precipitation seasonality; 10.9\%). The estimated LGM distribution was near the paleo-coastline with no inland potential distribution (Figure 7b). The potential value of more than 0.500 were shown in southern Kyushu, the central East China Sea, southeastern Taiwan, and the Ryukyu archipelago (Figure 7b).

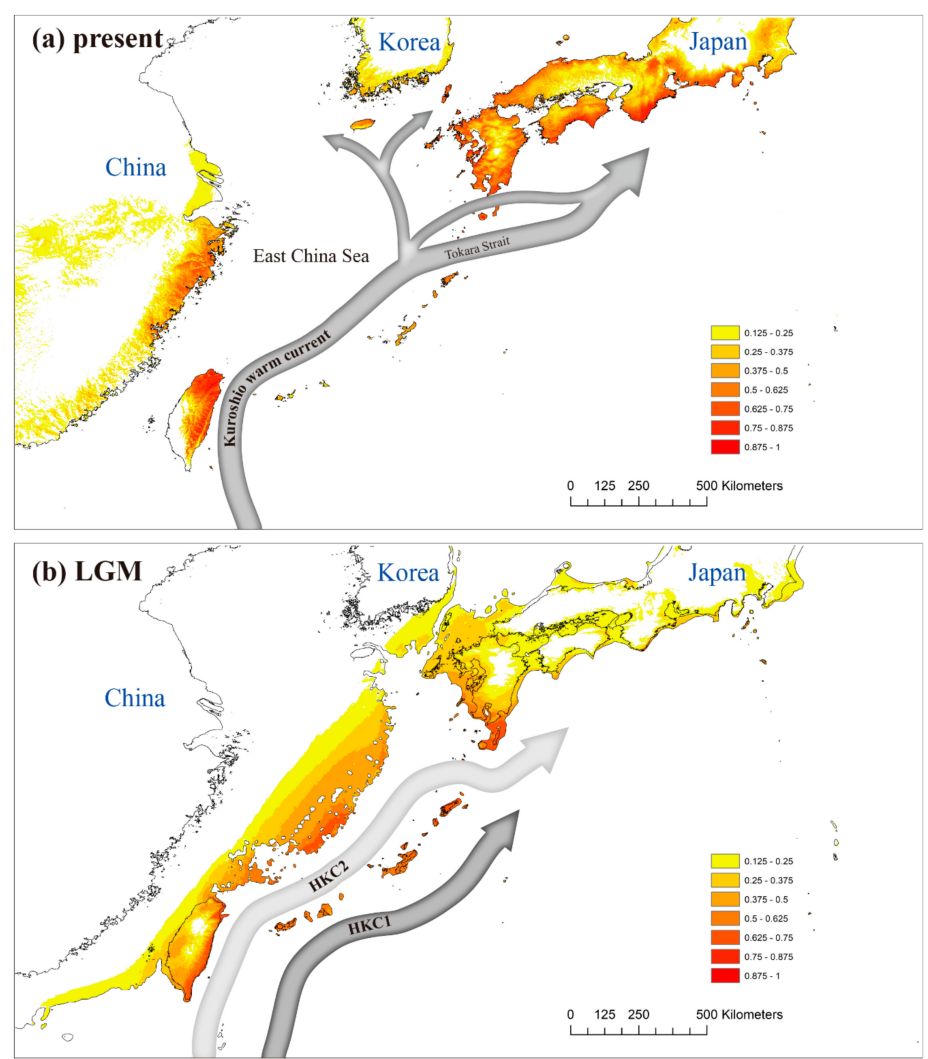

Figure 7. Potential distributions of Quercus gilva during (a) the present; (b) the Last Glacial Maximum, LGM. Distributions predicted by ecological niche modeling; potential distribution during the LGM was averaged from three general circulation models. HKC 1 indicates the main track of the Kuroshio Current during the LGM proposed by Ujiie et al. [66], Kao et al. [67], and Zheng et al. [68]. HKC 2 is the hypothetical Kuroshio Current during the LGM suggested by Vogt-Vincent and Mitarai [69]. 


\section{Discussion}

One of the most notable results of this study is that the geographically adjacent Jeju and Kyushu populations are genetically divergent. Comparison with other evergreen trees belonging to the same forest biomes may help to explain such a genetic pattern. Although the available data for genetic examination in this region are still minimal, consistent results point toward the fact that the warm temperate evergreen broad-leaved trees of South Korea, including the Jeju populations, have been affected by postglacial migration from those of Kyushu, Japan (Neolitsea sericea: [5]; Machilus thunbergii: [39]; Quercus acuta: [6]). Previous studies have shown that the Korean populations are homogeneous, with a genetic structure that is not very distinct from those of Kyushu, Japan. Furthermore, Q. gilva has an almost identical life history to Q. acuta; it is wind-pollinated, and the nuts contain a one-seeded fruit with a hard wall that is usually dispersed by small rodents such as squirrels and jays or animal-cached [70,71]. Therefore, the contrasting pattern of genetic structure suggest that historical factors are the most relevant. Therefore, we suggest that $Q$. gilva has a unique and separate evolutionary history.

Regardless of the latitude, the distribution of warm temperate evergreen broad-leaved forests in East Asia, such as in Korea, China, and Japan, is clearly related to the flow of the Kuroshio warm current (KC), showing a unique distribution structure [34,72,73]. Therefore, despite being located at relatively high latitudes, the southwestern portions of the Japanese main islands (i.e., southern areas of Kyushu, Shikoku, and Honshu) have long been regarded as crucial refugia with high genetic variation for evergreen broad-leaved trees that resulted from southward range shifts that paralleled glacial cycles [74-76]. ENM also revealed that Q. gilva populations are distributed like shadows along the flow of the present KC as well as the LGM (Figure 7). Therefore, considering the geographical location and population size of Jeju Island, it is worth noting that the levels of genetic diversity between the Jeju and Kyushu regions are almost equally similar in both populations and pooled regional populations. We found that the Jeju populations harbor a level of allele richness $\left(A_{\mathrm{R}}\right)$ and private allele rate $\left(P_{\text {riv }}\right)$ comparable to those of Kyushu populations. Although, such indicators provide a strong possibility for the existence of refugia in this area [77-79], we are convinced that Jeju Island did not serve as the glacial refuge of $Q$. gilva. In agreement with our assumption, ENM showed that the probability values for the distribution of the trees on Jeju Island during the LGM converged at zero. East Asian evergreen oaks prefer different habitats depending on the elevation gradient along the mountain slopes. A previous study suggested that Jeju Island was the refugia of Q. acuta [6], which occurs at the highest elevation range [80]. By comparison, Q. gilva shows a bias towards low-elevation stands, generally forming a community with Q. glauca [80]. In fact, Q. acuta occupies the middle of Mt. Halla on Jeju Island (approximately $600 \mathrm{~m}$ a.s.1.), while Q. gilva is distributed very close to the southern coastline (average: $168 \mathrm{~m}$ a.s.1.). It should be taken into account that the Quaternary climate oscillations caused not only latitudinal changes in the distribution of a given species but also vertical elevation migration [38]. During the glacial periods, in addition to the cold climate, competition for vertical migration with other oak species would have prompted the Jeju populations to retreat to low latitudes. The ENM revealed that, due to an apparent range contraction southward along the paleo $\mathrm{KC}$, with the exception of the Ryukyu Archipelago, the high distribution potentials have been narrowed to three places-southeastern Taiwan, central East China Sea, and southern Kyushu in LGM (Figure 7b). Given that the Jeju Island populations are genetically different from Kyushu's, the glacial refugia (i.e., genetic source) of the current Jeju populations would have most likely existed somewhere around the central East China Sea, which was land during the LGM.

One plausible scenario might be hypothesized for the unusual level of genetic diversity in Jeju Island, i.e., a massive postglacial immigration, demographically independent of Kyushu. Most oak species have common ecological traits, but their distinct adaptability also facilitates domination in such areas. In fact, evergreen Quercus species frequently dominate the landscape in extensive regions of East Asia, because they are better able to form dense and crowded stands [81,82]. In general, the larger the population is, the more reduced the effect of genetic drift is, which promotes a reduction in 
genetic diversity. We found no indication of significant recent bottlenecks, implying that the founding populations of $Q$. gilva might have been large enough to weaken the effect of genetic drift. Therefore, we suggest that a massive postglacial colonization, which maintained a high genetic diversity from separately stable and large genetic sources other than Kyushu, could have led to the current genetic diversity of Jeju Island. Further work using additional samples, including from broad areas such as the Ryukyu Islands and Eastern China, and the markers developed in this study might provide a better understanding of the historical migration of the warm temperate evergreen tree Q. gilva in Jeju Island. In particular, how the Jeju populations relate to East Asian populations other than Kyushu populations should be tested.

There are several definitions for determining the levels of CUs, such as Evolutionarily Significant Units (ESUs) and Management Units (MUs), because "high divergence" is too vague a term for practical purposes [83-85]. However, the criteria of the MUs clearly represent demographically independent units that merit separate management $[86,87]$. Considering the high genetic distinctiveness with a significant barrier, monophyletic phylogeny, population size, and other evidence, we suggest that the Jeju populations should be separately managed as a MU. The notable and unique genetic diversity of Jeju populations represents a high value in terms of conservation as it can contribute to the species' genetic diversity. Such genetic determinants should be well preserved and returned when East Asian populations are reconnected in response to the climate fluctuation. The low degree of genetic differentiation among the populations within Jeju Island suggests that all populations should be integrated and managed together rather than focusing conservation efforts on any particular subset of the population. From a long-term conservation genetics perspective, it is especially important for $Q$. gilva that conservation efforts should be focused on prohibiting the large-scale industrial development of the habitat, because large trees are not vulnerable to personal interference, such as overcollection. Thus, first, we recommend that all known habitats be protected in situ by law to prevent further damage. To prepare for inevitable land development, we suggest that ex situ preservation should be preceded by efforts to store good-quality seeds. Finally, if the artificial restoration of habitats is required, note that the source for the Jeju populations is not Kyushu.

Data Available: Sequence data for microsatellite loci developed in this study are available on GenBank (accession numbers MT811115-MT811160).

Author Contributions: E.-K.H. and W.-B.C. conducted data analyses and wrote the manuscript; E.-K.H. performed DNA extraction and PCR for genotyping and sequences; E.-K.H., W.-B.C., and J.H.L. performed the fieldwork; J.-S.P. performed the data analyses for the ENM; J.H.L., I.-S.C., and M.K. improved the manuscript; J.-H.L., B.-Y.K., and M.K. conceived and oversaw the study. All authors have read and agreed to the published version of the manuscript.

Funding: This research was funded by National Institute of Biological Resources, Korea, grant number NIBR201905102.

Acknowledgments: The authors thank G.H. Nam at the National Institute of Biological Resources for letting us distribute information of Jeju Island's plant materials. We are also grateful to the following researchers for commenting on a previous version of this manuscript: S. So (Korea National Park Research Institute), D. P. Jin (Inha University) and S. Yang (Korea Institute of Oriental Medicine).

Conflicts of Interest: The authors have no conflict of interest to declare.

\section{References}

1. Hewitt, G.M. Some genetic consequences of ice ages, and their role in divergence and speciation. Biol. J. Linn. Soc. 1996, 58, 247-276. [CrossRef]

2. Hewitt, G.M. The genetic legacy of the Quaternary ice ages. Nature 2000, 405, 907-913. [CrossRef] [PubMed]

3. Petit, R.J.; Aguinagalde, I.; De Beaulieu, J.-L.; Bittkau, C.; Brewer, S.; Cheddadi, R.; Ennos, R.; Fineschi, S.; Grivet, D.; Lascoux, M.; et al. Glacial Refugia: Hotspots but Not Melting Pots of Genetic Diversity. Science 2003, 300, 1563-1565. [CrossRef] [PubMed] 
4. $\quad$ Sakaguchi, S.; Qiu, Y.-X.; Liu, Y.-H.; Qi, X.-S.; Kim, S.-H.; Han, J.; Takeuchi, Y.; Worth, J.R.P.; Yamasaki, M.; Sakurai, S.; et al. Climate oscillation during the Quaternary associated with landscape heterogeneity promoted allopatric lineage divergence of a temperate tree Kalopanax septemlobus (Araliaceae) in East Asia. Mol. Ecol. 2012, 21, 3823-3838. [CrossRef] [PubMed]

5. Lee, J.H.; Lee, D.H.; Choi, B.H. Phylogeography and genetic diversity of East Asian Neolitsea sericea (Lauraceae) based on variations in chloroplast DNA sequences. J. Plant Res. 2013, 126, 193-202. [CrossRef]

6. Lee, J.H.; Lee, D.H.; Choi, I.S.; Choi, B.H. Genetic diversity and historical migration patterns of an endemic evergreen oak, Quercus acuta, across Korea and Japan, inferred from nuclear microsatellites. Plant Syst. Evol. 2014, 300, 1913-1923. [CrossRef]

7. Jin, D.P.; Lee, J.H.; Xu, B.; Choi, B.H. Phylogeography of East Asian Lespedeza buergeri (Fabaceae) based on chloroplast and nuclear ribosomal DNA sequence variations. J. Plant Res. 2016, 129, 793-805.

8. Tamaki, I.; Kawashima, N.; Setsuko, S.; Lee, J.-H.; Itaya, A.; Yukitoshi, K.; Tomaru, N. Population genetic structure and demography of Magnolia kobus: Variety borealis is not supported genetically. J. Plant Res. 2019, 132, 741-758. [CrossRef]

9. Harrison, S.P.; Yu, G.; Takahara, H.; Prentice, I.C. Palaeovegetation: Diversity of temperate plants in East Asia. Nature 2001, 413, 129-130. [CrossRef]

10. Alleaume-Benharira, M.; Pen, I.R.; Ronce, O. Geographical patterns of adaptation within a species' range: Interactions between drift and gene flow. J. Evol. Biol. 2006, 19, 203-215. [CrossRef]

11. Eckert, C.G.; Samis, K.E.; Lougheed, S.C. Genetic variation across species' geographical ranges: The central-marginal hypothesis and beyond. Mol. Ecol. 2008, 17, 1170-1188. [CrossRef] [PubMed]

12. Myking, T.; Vakkari, P.; Skrøppa, T. Genetic variation in northern marginal Taxus baccata L. populations. Implications for conservation. Forestry 2009, 82, 529-539. [CrossRef]

13. Villellas, J.; Ehrlén, J.; Olesen, J.M.; Braza, R.; Garcia, M. Plant performance in central and northern peripheral populations of the widespread Plantago coronopus. Ecography 2013, 36, 136-145. [CrossRef]

14. Mimura, M.; Aitken, S.N. Local adaptation at the range peripheries of Sitka spruce. J. Evol. Biol. 2010, 23, 249-258. [CrossRef] [PubMed]

15. Safriel, U.N.; Volis, S.; Kark, S. Core and peripheral populations and global climate change. Isr. J. Plant Sci. 1994, 42, 331-345. [CrossRef]

16. Gibson, S.Y.; Van Der Marel, R.C.; Starzomski, B.M. Climate change and conservation of leading-edge peripheral populations. Conserv. Biol. 2009, 23, 1369-1373. [CrossRef]

17. Milad, M.; Schaich, H.; Bürgi, M.; Konold, W. Climate change and nature conservation in Central European forests: A review of consequences, concepts and challenges. Ecol. Manag. 2011, 261, 829-843. [CrossRef]

18. Koskela, J.; Lefèvre, F.; Schueler, S.; Kraigher, H.; Olrik, D.C.; Hubert, J.; Yrjänä, L.; Alizoti, P.; Rotach, P. Translating conservation genetics into management: Pan-European minimum requirements for dynamic conservation units of forest tree genetic diversity. Biol. Conserv. 2013, 157, 39-49. [CrossRef]

19. Choi, I.S.; Lee, J.H.; Choi, B.H. Isolation and characterization of 12 microsatellite loci from Maackia fauriei (Fabaceae), a large tree endemic to Jeju Island. Conserv. Genet. Resour. 2014, 6, 1027-1029. [CrossRef]

20. Hong, Y.S.; Kim, E.J.; Lee, E.P.; Lee, S.Y.; Cho, K.; Lee, Y.K.; Chung, S.; Jeong, H.; You, Y.H. Characteristics of vegetation succession on the Pinus thunbergii forests in warm temperate regions, Jeju Island, South Korea. J. Ecol. Environ. 2019, 43, 1-16. [CrossRef]

21. Han, E.K.; Cho, W.B.; Choi, G.; Yang, S.; Choi, H.J.; Song, G.P.; Lee, J.H. New polymorphic microsatellite markers for Sarcandra glabra (Chloranthaceae), an evergreen broad-leaved shrub endangered in South Korea. J. For. Res. 2020, 25, 364-368. [CrossRef]

22. Noshiro, S.; Sasaki, Y. Identification of Japanese species of evergreen Quercus and Lithocarpus (Fagaceae). IAWA J. 2011, 32, 383-393. [CrossRef]

23. Tanouchi, H.; Yamamoto, S. Structure and regeneration of canopy species in an old-growth evergreen broad-leaved forest in Aya district, southwestern Japan. Vegetatio 1995, 117, 51-60. [CrossRef]

24. Zeng, Q.-M.; Liu, B.; Lin, R.-Q.; Jiang, Y.-T.; Liu, Z.-J.; Chen, S.-P. The complete chloroplast genome sequence of Quercus gilva (Fagaceae). Mitochondrial DNA Part B 2019, 4, 2493-2494. [CrossRef]

25. Kim, G.U.; Jang, K.S.; Lim, H.; Kim, E.H.; Lee, K.H. Genetic Diversity of Quercus gilva in Je-ju Island. J. Korean Soc. For. Sci. 2018, 107, 151-157. 
26. Sugiura, N.; Kurokochi, H.; Tan, E.; Asakawa, S.; Sato, N.; Saito, Y.; Ide, Y. Development of 13 polymorphic chloroplast DNA markers in Quercus gilva, a regionally endemic species in Japan. Conserv. Genet. Resour. 2014, 6, 961-965. [CrossRef]

27. Hyun, H.J.; Song, K.M.; Choi, H.S.; Kim, C.S. Dynamics and Distribution of Quercus gilva Blume Population in Korea. Korean J. Environ. Ecol. 2014, 28, 385-392. [CrossRef]

28. Ministry of the Environment of Korea. Korean Red List of Threatened Species; National Institute of Biological Resources: Incheon, Korea, 2012.

29. Suh, M.H.; Koh, K.S.; Ku, Y.B.; Kil, J.H.; Choi, T.B.; Suh, S.U.; Qiu, Y.X.; Liu, Y.H.; Oh, J.G. Research on the Conservation Strategy for the Endangered and Reserved Plants Based on the Ecological and Genetic Characteristics (I); National Institute of Environmental Research: Incheon, Korea, 2001.

30. Chung, M.Y.; López-Pujol, J.; Maki, M.; Kim, K.J.; Chung, J.M.; Sun, B.Y.; Chung, M.G. Genetic diversity in the common terrestrial orchid Oreorchis patens and its rare congener Oreorchis coreana: Inference of species evolutionary history and implications for conservation. J. Hered. 2012, 103, 692-702. [CrossRef]

31. Haig, S.M.; Miller, M.P.; Bellinger, R.; Draheim, H.M.; Mercer, D.M.; Mullins, T.D. The conservation genetics juggling act: Integrating genetics and ecology, science and policy. Evol. Appl. 2016, 9, 181-195. [CrossRef]

32. Stojnić, S.; Avramidou, E.; Fussi, B.; Westergren, M.; Orlović, S.; Matović, B.; Trudić, B.; Kraigher, H.; Aravanopoulos, F.A.; Konnert, M. Assessment of Genetic Diversity and Population Genetic Structure of Norway Spruce (Picea abies (L) Karsten) at Its Southern Lineage in Europe. Implications for Conservation of Forest Genetic Resources. Forests 2019, 10, 258. [CrossRef]

33. Chung, M.Y.; López-Pujol, J.; Chung, M.G. The role of the Baekdudaegan (Korean Peninsula) as a major glacial refugium for plant species: A priority for conservation. Biol. Conserv. 2017, 206, 236-248. [CrossRef]

34. Aoki, K.; Tamaki, I.; Nakao, K.; Ueno, S.; Kamijo, T.; Setoguchi, H.; Murakami, N.; Kato, M.; Tsumura, Y. Approximate Bayesian computation analysis of EST-associated microsatellites indicates that the broadleaved evergreen tree Castanopsis sieboldii survived the Last Glacial Maximum in multiple refugia in Japan. Heredity 2019, 122, 326-340. [PubMed]

35. Park, J.S.; Takayama, K.; Suyama, Y.; Choi, B.-H. Distinct phylogeographic structure of the halophyte Suaeda malacosperma (Chenopodiaceae/Amaranthaceae), endemic to Korea-Japan region, influenced by historical range shift dynamics. Plant Syst. Evol. 2019, 305, 193-203. [CrossRef]

36. Chen, D.; Zhang, X.; Kang, H.; Sun, X.; Yin, S.; Du, H.; Yamanaka, N.; Gapare, W.; Wu, H.X.; Liu, C. Phylogeography of Quercus variabilis based on chloroplast DNA sequence in East Asia: Multiple glacial refugia and mainland-migrated island populations. PLoS ONE 2012, 7, e47268. [CrossRef] [PubMed]

37. Tang, C.Q.; Matsui, T.; Ohashi, H.; Dong, Y.-F.; Momohara, A.; Herrando-Moraira, S.; Qian, S.; Yang, Y.; Ohsawa, M.; Luu, H.T.; et al. Identifying long-term stable refugia for relict plant species in East Asia. Nat. Commun. 2018, 9, 4488. [CrossRef]

38. Cho, W.B.; So, S.K.; Han, E.K.; Myeong, H.H.; Park, J.S.; Hwang, S.H. Rear-edge, low-diversity, and haplotypic uniformity in cold-adapted Bupleurum euphorbioides interglacial refugia populations. Ecol. Evol. 2020, in press.

39. Chung, M.Y.; López-Pujol, J.; Chung, M.G. Genetic homogeneity between Korean and Japanese populations of the broad-leaved evergreen tree Machilus thunbergii (Lauraceae): A massive post-glacial immigration through the Korea Strait or something else? Biochem. Syst. Ecol. 2014, 53, 20-28. [CrossRef]

40. Cho, W.B.; Choi, I.S.; Choi, B.H. Development of microsatellite markers for the endangered Pedicularis ishidoyana (Orobanchaceae) using next-generation sequencing. Appl. Plant Sci. 2015, 3, 1500083. [CrossRef]

41. Miller, M.P.; Knaus, B.J.; Mullins, T.D.; Haig, S.M. SSR_pipeline: A Bioinformatic Infrastructure for Identifying Microsatellites from Paired-End Illumina High-Throughput DNA Sequencing Data. J. Hered. 2013, 104, 881-885. [CrossRef]

42. Kearse, M.; Moir, R.; Wilson, A.; Stones-Havas, S.; Cheung, M.; Sturrock, S.; Cooper, A.; Markowitz, S.; Drummond, A. Geneious Basic: An integrated and extendable desktop software platform for the organization and analysis of sequence data. Bioinformatics 2012, 28, 1647-1649.

43. Rozen, S.; Skaletsky, H. Primer3 on the WWW for general users and for biologist programmers. In Bioinformatics Methods and Protocols; Humana Press: Totowa, NJ, USA, 2000; pp. 365-386.

44. Chybicki, I.J.; Burczyk, J. Simultaneous estimation of null alleles and inbreeding coefficients. J. Hered. 2009, 100, 106-113. [CrossRef]

45. Peakall, R.; Smouse, P.E. genalex 6: Genetic analysis in Excel. Population genetic software for teaching and research. Mol. Ecol. Notes 2006, 6, 288-295. [CrossRef] 
46. Weir, B.S.; Cockerham, C.C. Estimating F-statistics for the analysis of population structure. Evolution 1984, 38, 1358-1370. [CrossRef] [PubMed]

47. Goudet, J. FSTAT (version 1.2): A computer program to calculate F-statistics. J. Hered. 1995, 86, 485-486. [CrossRef]

48. Rousset, F. genepop'007: A complete re-implementation of the genepop software for Windows and Linux. Mol. Ecol. Resour. 2008, 8, 103-106. [CrossRef]

49. Cornuet, J.M.; Luikart, G. Description and power analysis of two tests for detecting recent population bottlenecks from allele frequency data. Genetics 1996, 144, 2001-2014. [PubMed]

50. Luikart, G. Distortion of allele frequency distributions provides a test for recent population bottlenecks. J. Hered. 1998, 89, 238-247. [CrossRef] [PubMed]

51. Pritchard, J.K.; Stephens, M.; Donnelly, P. Inference of population structure using multilocus genotype data. Genetics 2000, 155, 945-959.

52. Earl, D.A.; vonHoldt, B.M. STRUCTURE HARVESTER: A website and program for visualizing STRUCTURE output and implementing the Evanno method. Conserv. Genet. Resour. 2012, 4, 359-361. [CrossRef]

53. Jakobsson, M.; Rosenberg, N.A. CLUMPP: A cluster matching and permutation program for dealing with label switching and multimodality in analysis of population structure. Bioinformatics 2007, 23, 1801-1806. [CrossRef]

54. Manni, F.; Guérard, E.; Heyer, E. Geographic patterns of (genetic, morphologic, linguistic) variation: How barriers can be detected by using Monmonier's algorithm. Hum. Biol. 2004, 76, 173-190. [CrossRef] [PubMed]

55. Monmonier, M.S. Maximum-Difference Barriers: An Alternative Numerical Regionalization Method. Geogr. Anal. 1973, 5, 245-261. [CrossRef]

56. Nei, M.; Tajima, F. Maximum Likelihood Estimation of the Number of Nucleotide Substitutions from Restriction Sites Data. Genetics 1983, 105, 207-217.

57. Dieringer, D.; Schlötterer, C. Two distinct modes of microsatellite mutation processes: Evidence from the complete genomic sequences of nine species. Genome Res. 2003, 13, 2242-2251. [CrossRef] [PubMed]

58. Felsenstein, J. PHYLIP (Phylogeny Inference Package) Version 3.6; Department of Genome Sciences, University of Washington: Washington, DC, USA, 2004.

59. Merow, C.; Smith, M.J.; Silander, J.A. A practical guide to MaxEnt for modeling species' distributions: What it does, and why inputs and settings matter. Ecography 2013, 36, 1058-1069. [CrossRef]

60. GBIF Secretariat. GBIF Backbone Taxonomy Checklist dataset. GBIF Backbone Taxon. 2019. [CrossRef]

61. Brown, J.L.; Bennett, J.R.; French, C.M. SDMtoolbox 2.0: The next generation Python-based GIS toolkit for landscape genetic, biogeographic and species distribution model analyses. PeerJ 2017, 5, e4095. [CrossRef]

62. Karger, D.N.; Conrad, O.; Böhner, J.; Kawohl, T.; Kreft, H.; Soria-Auza, R.W.; Zimmermann, N.E.; Linder, H.P.; Kessler, M. Climatologies at high resolution for the earth's land surface areas. Sci. Data 2017, 4, 1-20. [CrossRef]

63. Danielson, J.J.; Gesch, D.B. Global Multi-Resolution Terrain Elevation Data 2010 (GMTED2010). In Geological Survey; Springer: Garretson, SD, USA, 2011.

64. Gent, P.R.; Danabasoglu, G.; Donner, L.J.; Holland, M.M.; Hunke, E.C.; Jayne, S.R.; Lawrence, D.M.; Neale, R.B.; Rasch, P.J.; Vertenstein, M.; et al. The Community Climate System Model Version 4. J. Clim. 2011, 24, 4973-4991. [CrossRef]

65. Watanabe, S.; Hajima, T.; Sudo, K.; Nagashima, T.; Takemura, T.; Okajima, H.; Nozawa, T.; Kawase, H.; Abe, M.; Yokohata, T.; et al. MIROC-ESM 2010: Model description and basic results of CMIP5-20c3m experiments. Geosci. Model Dev. 2011, 4, 845-872. [CrossRef]

66. Ujiié, Y.; Ujiié, H.; Taira, A.; Nakamura, T.; Oguri, K. Spatial and temporal variability of surface water in the Kuroshio source region, Pacific Ocean, over the past 21,000 years: Evidence from planktonic foraminifera. Mar. Micropaleontol. 2003, 49, 335-364. [CrossRef]

67. Kao, S.J.; Wu, C.R.; Hsin, Y.C.; Dai, M. Effects of sea level change on the upstream Kuroshio Current through the Okinawa Trough. Geophys. Res. Lett. 2006, 33. [CrossRef]

68. Zheng, X.; Li, A.; Kao, S.; Gong, X.; Frank, M.; Kuhn, G.; Cai, W.; Yan, H.; Wan, S.; Zhang, H.-H.; et al. Synchronicity of Kuroshio Current and climate system variability since the Last Glacial Maximum. Earth Planet. Sci. Lett. 2016, 452, 247-257. [CrossRef] 
69. Vogt-Vincent, N.S.; Mitarai, S. A persistent Kuroshio in the glacial East China Sea and implications for coral paleobiogeography. Paleoceanogr. Paleoclimatol. 2020, e2020PA003902. [CrossRef]

70. Janzen, D.H. Seed predation by animals. Annu. Rev. Ecol. Syst. 1971, 2, 465-492.

71. Xiao, Z.; Zhibin, Z.; Wang, Y. Dispersal and germination of big and small nuts of Quercus serrata in a subtropical broad-leaved evergreen forest. Ecol. Manag. 2004, 195, 141-150. [CrossRef]

72. Tsukada, M. Vegetation and Climate during the Last Glacial Maximum in Japan. Quat. Res. 1983, 19, $212-235$. [CrossRef]

73. Lee, J.H.; Choi, B.-H. Distribution of broad-Leaved evergreen plants on islands of Incheon, middle part of Yellow Sea. Korean J. Plant Taxon. 2008, 38, 315-332. [CrossRef]

74. Aoki, K.; Suzuki, T.; Hsu, T.W.; Murakami, N. Phylogeography of the component species of broad-leaved evergreen forests in Japan, based on chloroplast DNA variation. J. Plant Res. 2004, 117, 77-94.

75. Aoki, K.; Matsumura, T.; Hattori, T.; Murakami, N. Chloroplast DNA phylogeography of Photinia glabra (Rosaceae) in Japan. Am. J. Bot. 2006, 93, 1852-1858. [CrossRef]

76. Liu, H.-Z.; Takeichi, Y.; Kamiya, K.; Harada, K. Phylogeography of Quercus phillyraeoides (Fagaceae) in Japan as revealed by chloroplast DNA variation. J. Res. 2013, 18, 361-370. [CrossRef]

77. Litkowiec, M.; Lewandowski, A.; Rączka, G. Spatial Pattern of the Mitochondrial and Chloroplast Genetic Variation in Poland as a Result of the Migration of Abies alba Mill. From Different Glacial Refugia. Forests 2016, 7, 284. [CrossRef]

78. Hou, Z.; Wang, Z.; Ye, Z.; Du, S.; Liu, S.; Zhang, J. Phylogeographic analyses of a widely distributed Populus davidiana: Further evidence for the existence of glacial refugia of cool-temperate deciduous trees in northern East Asia. Ecol. Evol. 2018, 8, 13014-13026. [CrossRef] [PubMed]

79. Di Pasquale, G.; Saracino, A.; Bosso, L.; Russo, D.; Moroni, A.; Bonanomi, G.; Allevato, E. Coastal Pine-Oak Glacial Refugia in the Mediterranean Basin: A Biogeographic Approach Based on Charcoal Analysis and Spatial Modelling. Forests 2020, 11, 673. [CrossRef]

80. Ito, S.; Ohtsuka, K.; Yamashita, T. Ecological distribution of seven evergreen Quercus species in southern and eastern Kyushu, Japan. Veg. Sci. 2007, 24, 53-63.

81. Nakashizuka, T.; Iida, S. Composition, dynamics and disturbance regime of temperate deciduous forests in Monsoon Asia. Vegetatio 1995, 121, 23-30. [CrossRef]

82. Nakao, K.; Matsui, T.; Horikawa, M.; Tsuyama, I.; Tanaka, N. Assessing the impact of land use and climate change on the evergreen broad-leaved species of Quercus acuta in Japan. Plant Ecol. 2011, 212, 229-243.

83. Moritz, C. Defining 'Evolutionarily Significant Units' for conservation. Trends Ecol. Evol. 1994, 9, $373-375$. [CrossRef]

84. Crandall, K.A.; Bininda-Emonds, O.R.; Mace, G.M.; Wayne, R.K. Considering evolutionary processes in conservation biology. Trends Ecol. Evol. 2000, 15, 290-295. [CrossRef]

85. Fraser, D.J.; Bernatchez, L. Adaptive evolutionary conservation: Towards a unified concept for defining conservation units. Mol. Ecol. 2001, 10, 2741-2752. [CrossRef]

86. Palsbøll, P.J.; Bérubé, M.; Allendorf, F.W. Identification of management units using population genetic data. Trends Ecol. Evol. 2006, 22, 11-16. [CrossRef] [PubMed]

87. Waples, R.S.; Lindley, S.T. Genomics and conservation units: The genetic basis of adult migration timing in Pacific salmonids. Evol. Appl. 2018, 11, 1518-1526. [CrossRef] [PubMed]

(C) 2020 by the authors. Licensee MDPI, Basel, Switzerland. This article is an open access article distributed under the terms and conditions of the Creative Commons Attribution (CC BY) license (http://creativecommons.org/licenses/by/4.0/). 